\title{
Reviu Strategi Pencegahan Perilaku Berisiko pada Pemuda di RPJMN 2020-2024
}

\section{Review of Risky Behavior Prevention Strategies in Youth in RPJMN 2020-2024}

\author{
Indra Prasetya Adi Nugroho
}

Kementerian Koordinator Bidang Pembangunan Manusia dan Kebudayaan

\section{Penulis Korespondensi}

Indra Prasetya Adi Nugroho indra.kpmk@gmail.com +6282112069613

\begin{abstract}
Abstrak
Sumpah pemuda hadir 93 tahun yang lalu atas dasar kesepemahaman yang sama atas keragaman adat, suku, budaya, bahasa untuk memperjuangkan kemerdekaan Indonesia dan melawan penjajah. Setelah 93 tahun sumpah pemuda berlalu para pemuda Indonesia dihadapkan pada ancaman yang sangat berbeda yaitu bukan lagi penjajah secara harfiah melainkan 'penjajahan' dari sisi fisik dan psikis pemuda termasuk dampak dari perkembangan teknologi. Saat ini pemuda dihadapkan pada ancaman perilaku berisiko seperti penyalahgunaan narkotika, psikotropika, dan zat adiktif lainnya (NAPZA), perilaku seksual berisiko, kekerasan dan perundungan, yang ke semuanya dapat menghambat pemuda melakukan tugasnya sebagai generasi penerus bangsa yang berkualitas. Melalui RPJMN 2020-2024, dalam rangka pembangunan SDM berkualitas, pemerintah telah menentukan salah satu proyek prioritasnya yaitu peningkatan kualitas pemuda, dengan satu dari tiga strategi yang ada adalah pencegahan perilaku berisiko pada pemuda. Tulisan ini menganalisis apakah strategi pemerintah melalui pencegahan perilaku berisiko pada pemuda yang dilakukan sudah tepat untuk menjawab pembangunan SDM berkualitas. Studi ini menggunakan pendekatan kualitatif yaitu studi kasus. Tiga teori digunakan dalam analisis tulisan ini yaitu teori pencegahan, teori perilaku dan teori risiko. Studi ini menyimpulkan (3) temuan penting. Pertama, proyek yang ditentukan masih berkutat pada aspek kuantitas Kedua, kualitas sosialisasi dan edukasi masih terbatas cakupannya, dan Ketiga, belum adanya kajian khusus terhadap akar permasalahan. Dengan demikian, perlu dilakukan perbaikan dalam rencana kerja pemerintah ke depan, khususnya tentang pemilihan proyek yang mendukung dalam pencegahan perilaku berisiko pemuda. Strategi pencegahan perilaku berisiko pada pemuda akan meningkatkan kualitas dan kapasitas pemuda Indonesia menyongsong bonus demografi tahun 2030 dan Indonesia emas pada tahun 2045 melalui strategi pencegahan perilaku berisiko pada pemuda.
\end{abstract}

\section{Kata Kunci}

Sumpah Pemuda; peningkatan kualitas pemuda; peningkatan kapasitas pemuda; bonus demografi; Indonesia Emas; perilaku berisiko pemuda

\section{Abstract}

The youth oath was present 93 years ago on the basis of the same understanding of the diversity of customs, tribes, cultures, languages to fight for Indonesian independence and against invaders. After 93 years of youth vows passed the youth of Indonesia are faced with a very different threat that is no longer a literal invader but a 'colonization' from the physical and psychological side of youth including the impact of technological developments. Currently youth are faced with the threat of risky behaviors such as narcotics abuse, psychotropic, and other addictive substances (NAPZA), risky sexual behavior, violence and bullying, which can all hinder youth from doing their job as the next generation of qualified nations. Through RPJMN 2020-2024, in the framework of quality human resource development, the government has determined one of its priority projects is improving youth quality, with one of three existing strategies being the prevention of risky behavior in youth. This paper analyzes whether the government's strategy through the prevention of risky behavior in youth is appropriate to answer the development of quality human resources. 
ARTIKEL

This study uses a qualitative approach that is case studies. Three theories are used in the analysis of this paper: prevention theory, behavioral theory and risk theory. The study concluded (3) important findings. First, the project specified still dwells on the second quantity aspect, the quality of socialization and education is still limited in scope, and third, there is no special study of the root cause. Thus, improvements are needed in the government's work plan going forward, particularly about the selection of projects that support in the prevention of youth risky behavior. Risky behavior prevention strategies in youth will improve the quality and capacity of Indonesian youth to meet the demographic bonus in 2030 and Indonesia gold in 2045 through risky behavior prevention strategies in youth.

\section{Keywords}

Youth Oath; improving the quality of youth; increase in youth capacity; demographic bonus; Indonesia Gold; youth risky behavior 


\section{Pendahuluan}

Berawal dari berkumpulnya organisasi kesukuan/etnis/ adat/agama yang terserak di seluruh penjuru pulau pulau untuk bersatu dan memperjuangkan nasib mereka sebagai sebuah entitas kebangsaan, maka lahirlah embrio persatuan nasional melalui kongres pemuda yang menghasilkan sumpah pemuda dan kemudian melengkapi pergerakan kebangkitan nasional beberapa waktu sebelumnya (Direktorat Jenderal Kebudayaan Kemendikbud, 2016; Goebel, 2013, hlm. 1-34; Paauw, 2009; Sari \& Rizqi, 2019).

Embrio inilah yang kemudian dipertegas dan diperkokoh pada masa-masa selanjutnya oleh para pemuda sebagai jalan rintisan kemerdekaan Indonesia pada tahun 1945 (Rahmat, 2003). Oleh karenanya tidaklah mengherankan jika salah satu pendiri bangsa kita yaitu Ir. Sukarno menyebutkan beri saya 10 pemuda maka akan saya guncang dunia. Pemuda tak dipungkiri merupakan unsur penting tonggak berdirinya negara dan bangsa Indonesia yang akan tetap dibutuhkan kehadirannya secara maksimal di masa-masa mendatang (Foulcher, 2000, hlm. 377-410; Freedman, 2017; Sebastian dkk., 2014; Sudira, n.d.; Tan, 2020; Widodo, 2012).

Tantangan pemuda dalam setiap masa akan berbeda. Hampir 100 tahun yang lalu, pemuda Indonesia bersumpah bersama untuk memerdekakan diri bangsa dari penjajahan, saat ini, pemuda Indonesia dihadapkan pada penjajahan baru yaitu realitas ancaman perilaku berisiko seperti penyalahgunaan narkotika, psikotropika, dan zat adiktif lainnya (NAPZA), perilaku seksual berisiko, perundungan serta lainnya. Berdasarkan peraturan perundangan yang ada yaitu Undang-Undang Nomor 40 Tahun 2009 tentang Kepemudaan disebutkan bahwa pemuda adalah warga negara Indonesia yang berusia 16-30 tahun dan berada dalam periode penting usia pertumbuhan dan perkembangan.

Kuantitas pemuda Indonesia saat ini menyentuh angka 64,5 juta jiwa atau sekitar $23,86 \%$ dari jumlah penduduk Indonesia, di mana lebih dari separuh pemuda atau sekitar 55,11\% berada di pulau Jawa (Badan Pusat Statistik, 2020b). Kemajuan teknologi telah mendorong pemuda untuk hidup berdampingan dengan gawai, di mana $88,77 \%$ pemuda memiliki gawai dan $85,62 \%$ pemuda menggunakan internet dalam 3 bulan terakhir (Badan Pusat Statistik, 2021).

Masih dalam laporan yang sama, kualitas pemuda Indonesia menghadapi beberapa ancaman permasalahan baru misalnya sekitar $2,16 \%$ pemuda melakukan perkawinan di bawah usia 16 tahun, 20,92\% pemuda pernah mengalami keluhan kesehatan, 1 dari 4 pemuda merupakan perokok dengan persentase tertinggi di usia 25-30 tahun yaitu sekitar $41,68 \%$, hanya $10,36 \%$ pemuda Indonesia yang menyelesaikan pendidikan hingga perguruan tinggi, 21,08\% pemuda usia 16-18 tahun sudah bekerja dan angka tingkat pengangguran terbuka pemuda menyentuh angka 15,23\% atau dapat diartikan di setiap 100 pemuda terdapat 15 pemuda yang tidak bekerja.

Dari berbagai fakta dan realitas di atas, tulisan ini bermaksud untuk mereviu dan menelaah strategi yang diambil oleh pemerintah untuk meningkatkan kualitas pemuda dalam RPJMN 2020-2024 yaitu apakah pencegahan perilaku berisiko pada pemuda sudah tepat untuk menjawab tantangan/permasalahan mereka.

Tujuan utama dari tulisan ini adalah memetakan dan menganalisis strategi yang telah ditetapkan pemerintah sudah tepat atau belum dalam rangka menjawab tantangan para pemuda di lapangan dan peningkatan kualitas serta kapasitas pemuda sebagai generasi penerus bangsa ke depan. Oleh karena strategi inilah yang kemudian akan memiliki peranan penting dalam meningkatkan kualitas dan kapasitas pemuda dalam rangka menyongsong bonus demografi pada 2030 dan Indonesia emas tahun 2045.

\subsection{Teori}

Untuk menganalisis pokok permasalahan tulisan yaitu sudah tepat atau belum pencegahan perilaku berisiko pada pemuda menjadi strategi dalam peningkatan kualitas pemuda, penulis mencoba membahasnya melalui 3 teori yaitu teori pencegahan, teori perilaku dan teori risiko. Penulis menganggap bahwa ketiga teori tersebut akan membedah strategi dan proyek atau program turunan yang ada dari sisi pencegahan, sisi perilaku dan sisi risiko.

Ketiganya akan dijadikan dasar pembahasan pada bab analisis, di mana penulis menelaah RPJMN 2020-2024 khususnya pada tema pencegahan perilaku berisiko pada 
pemuda. Apakah kemudian dari proyek dan kegiatan yang disebutkan di RPJMN sudah sesuai dengan ketiga teori tersebut sebagai strategi yang andal.

Hubungan ketiga teori tersebut adalah saling terikatnya satu sama lain dalam konteks strategi pencegahan perilaku berisiko pada pemuda terhadap tujuan pembangunan sumber daya manusia berkualitas dan berdaya saing sebagaimana termaktub dalam RPJMN. Teori pencegahan memberikan kisi-kisi tentang apa saja yang seharusnya dijadikan proyek prioritas dalam rangka pencegahan, di mana sangat terkait dengan teori perilaku dan risiko, yaitu menyangkut aksi dan respons di mana akan meningkatkan kadar risiko yang pada akhirnya memberikan ancaman terhadap pencapaian target yang ada.

\subsubsection{Teori Pencegahan}

Menurut Richard Freeman (1995, hlm. 745-765) di dalam Ian Gough (2013) disebutkan bahwa setidaknya ada 2 (dua) arti pencegahan dalam kebijakan yaitu 1). Pemahaman ilmiah terhadap penyebab dan dampak serta kemungkinan prediksi, dan 2). Kapasitas atau kemampuan pemerintah untuk melakukan intervensi dan mengontrol kehidupan sosial (Gough, 2013). Berdasarkan teori tersebut maka fokus pencegahan menitikberatkan pada fase inventarisasi risiko dan kemungkinan dampak yang ditimbulkan sebagai bahan dasar pembuatan kebijakan dalam melakukan intervensi agar dampak sosial di lapangan bisa dikontrol.

Menurut Morton M. Silverman (2003) secara tradisional, pencegahan primer secara dominan berfokus pada modalitas pendidikan, dorongan motivasi, dukungan sosial, hukum dan kebijakan, perubahan lingkungan fisik dan sejenisnya (Silverman, 2003, hlm. 27-42). Teori ini mengutamakan pada pembenahan secara awal di hulu permasalahan yaitu melalui saluran modalitas yang ada di lapangan, misalnya pada pemberian edukasi yang baik dan benar terhadap risiko dan dampak yang dihadapi terhadap salah satu perilaku. Teori ini juga menghadirkan wajah psikologi seperti pemberian motivasi dan dukungan baik dari sisi hukum maupun sosial di masyarakat sehingga mereka akan lebih memiliki daya redam terhadap risiko dari perilaku yang dipilih.
Teori pencegahan sangat erat kaitannya dengan tindakan kejahatan dan promosi kesehatan. Beberapa literatur menyepakati bahwa teori pencegahan di dalam dunia kriminal misalnya pendekatan tradisional pencegahan dengan cara identifikasi sebab psikologis dan sosial kemudian merancang layanan pendidikan serta pekerjaan khusus kepada kelompok berisiko (Geason \& Wilson, 1988; Massetti \& David-Ferdon, 2016; Meško \& Muršič, 2003; World Health Organization, 2014).

Memang benar adanya bahwa baik di dalam literatur dalam negeri maupun literatur asing, pembahasan teori pencegahan ini sangat erat kaitannya dengan dunia kriminalitas dan kesehatan. Dua dunia yang menjadi pokok pembahasan teori pencegahan ini di mana menurut hemat penulis dikarenakan fokus dari para scholar dalam rangka mengatasi dampak negatif dari dunia kriminalitas dan dunia kesehatan di kehidupan sosial bermasyarakat. Tidak jarang para pelaku tindak kriminalitas seperti pencuri, dan penyimpangan kesehatan seperti penyalahgunaan obat-obatan, menjadi bulan-bulanan dan dijadikan pesakitan serta target pemberian sanksi sosial pada akhirnya.

Kaitan utama teori pencegahan dengan strategi pencegahan perilaku berisiko pada pemuda adalah pada poin ada tidaknya proyek atau kegiatan di dalam RPJMN 2020-2024 terkait dengan penyiapan saluran modalitas seperti sosialisasi dan edukasi kepada pemuda terkait perilaku-perilaku yang memiliki risiko tinggi bagi mereka.

\subsubsection{Teori Perilaku}

Teori perilaku didasarkan pada positivisme logis di mana satu satunya pengetahuan yang valid adalah yang diamati secara objektif (Maag, 2014). Sebagai sebuah bagian aktivitas dari suatu organisme, perilaku adalah apa yang dilakukan dan diamati oleh organisme lain dan merupakan respons atau reaksi terhadap rangsangan dari luar (Pakpahan dkk., 2021).

Setidaknya ada 2 teori perilaku yang terkenal di dunia yaitu teori organisme stimulus atau lazim disebut Stimulus Organism Response (S-O-R) dan perilaku organisme, yaitu segala sesuatu yang dilakukan termasuk perilaku tertutup dan terbuka (Pakpahan dkk., 2021).

Teori perilaku atau behavioral theory memang tidak bisa dilepaskan dari respons, aksi dan reaksi organisme 
yang ada di dunia. Apa saja yang dilakukan oleh organisme merupakan aksi dan reaksi dari perilaku organisme lain yang berinteraksi baik secara langsung maupun tidak langsung dengannya. Dalam konteks ini, perilaku berisiko pada pemuda akan sangat tergantung dari banyak perilaku yang melingkupinya misalnya perilaku dalam keluarga, perilaku teman sebaya, dan perilaku dari tontonan yang mereka lihat baik dari media sosial, cetak, maupun media lainnya termasuk juga pendidikan (Savitri \& Listiyandini, 2017, hlm. 43-59; Kaloeti dkk., 2021, hlm. 1-10; Permatasari \& Suprayitno, 2020; Rinta, 2015; Sutopo \& Meiji, 2017).

Kaitan utama teori perilaku dengan strategi pencegahan perilaku berisiko pada pemuda adalah pada poin ada tidaknya proyek atau kegiatan di dalam RPJMN 2020-2024 terkait dengan aksi pemerintah merespons perkembangan permasalahan perilaku berisiko pada pemuda yang ada di lapangan seperti penyalahgunaan NAPZA, perilaku seksual berisiko, perundungan dan sebagainya.

\subsubsection{Teori Risiko}

Teori risiko ilmiah didasarkan pada teori probabilitas dan semua kesalahan distribusi diberikan dalam pengertian stokastik (acak). Risiko selalu terkait dengan banyak variabel, elemen dan berakhir dengan klaim (Almer, 1967, hlm. 136-169; Martin-Löf \& Sköllermo, 2011). Pada lazimnya, apabila teori pencegahan akan lebih dekat dengan dunia kriminalitas dan kesehatan, maka teori risiko ini memang sangat dekat dengan dunia ekonomi dan matematika. Risiko akan sangat erat kaitannya dengan kemungkinan-kemungkinan atau probabilitas yang ada dari sebuah tindakan atau aksi. Lahirnya kemungkinan-kemungkinan itulah yang dikaitkan dengan elemen yang melingkupinya yaitu variabelvariabel. Di mana pada akhirnya risiko akan berujung pada sebuah klaim bahwa kemungkinan akan menghasilkan sebuah dampak yang harus dibayar secara pasti oleh organisme.

Risiko adalah kemungkinan terjadinya peristiwa yang tidak menguntungkan (Plackett, 2016). Risiko adalah ukuran kemungkinan dan tingkat keparahan efek samping atau seberapa besar kemungkinan sebuah insiden akan terjadi dan seberapa besar konsekuensinya (Campbell Institute, 2016). Risiko memiliki konotasi negatif yang tidak disukai, dan ingin dihindari. Risiko erat kaitannya dengan kondisi ketidakpastian dan cenderung meningkat dari tahun ke tahun. 2 (dua) tipe risiko yang ada yaitu risiko murni (kemungkinan yang ada hanya kerugian) dan risiko spekulatif (kemungkinan kerugian dan keuntungan ada) (Hanafi, 2014).

Risiko adalah kemungkinan kejadian yang mengancam pencapaian tujuan dan sasaran instansi pemerintah (Peraturan Pemerintah Nomor 60 tahun 2008 tentang Sistem Pengendalian Intern Pemerintah, 2008). Tidak dipungkiri bahwa risiko akan selalu berhubungan dengan konotasi negatif, karena memanglah sebuah hal yang tidak diharapkan untuk terjadi, tapi selalu muncul dalam analisis yang dilakukan oleh organisme. Meskipun ada juga yang melihat bahwa risiko juga memiliki sisi spekulatif di mana tidak selamanya dia mendatangkan sisi negatif melainkan juga sisi positif yang menguntungkan baik secara bersamaan maupun tidak bagi organisme.

Dalam konteks pencegahan perilaku berisiko pada pemuda, konsep risiko ini lebih merujuk pada pendapat utama yang menyatakan bahwa risiko mendatangkan konotasi negatif dan tidak menguntungkan bagi organisme. Bagi penulis sendiri, tidak melihat dan meyakini satu pun sisi positif yang menguntungkan dari tingginya angka kesakitan para pemuda dikarenakan rokok, NAPZA, seks bebas (di luar nikah) dan perundungan yang ada.

Kaitan utama teori risiko dengan strategi pencegahan perilaku berisiko pada pemuda adalah pada poin ada tidaknya proyek atau kegiatan di dalam RPJMN 2020-2024 terkait dengan aksi pemerintah merespons perkembangan permasalahan perilaku berisiko pada pemuda yang dapat mengancam tercapainya target pembangunan SDM berkualitas dan berdaya saing.

\subsection{Konsep Pemuda}

Menurut Undang-Undang Nomor 40 Tahun 2009 tentang Kepemudaan, pemuda adalah warga negara Indonesia yang memasuki periode penting pertumbuhan dan perkembangan yang berusia 16 (enam belas) sampai dengan 30 (tiga puluh) tahun. Usia 16-30 tahun ini memiliki beberapa persimpangan dengan usia intervensi program lain, yaitu usia anak dan remaja yang juga memiliki perbedaan kriteria di antara instansi yang 
ada. Menurut Undang-Undang Nomor 35 tahun 2014 tentang Perubahan Atas Undang-Undang Nomor 23 Tahun 2002 tentang Perlindungan Anak, Anak adalah seseorang yang belum berusia 18 (delapan belas) tahun, termasuk anak yang masih dalam kandungan. Ini adalah persimpangan pertama usia pemuda dengan usia intervensi dari program lain yaitu anak.

Persimpangan kedua adalah dengan remaja, menurut World Health Organization (WHO) usia remaja berada dalam kurun usia 10-19 tahun dan pemuda dalam kurun usia 15-24 tahun (Pusat Data dan Informasi Kementerian Kesehatan Republik Indonesia, 2015). Sedangkan menurut dua instansi pemerintah yang melakukan intervensi program dan kegiatan secara langsung pada remaja yaitu Kemenkes dan BKKBN, usia remaja sedikit berbeda dengan pendekatan dari WHO di atas. Berdasarkan Peraturan Menteri Kesehatan Nomor 25 Tahun 2014 tentang Upaya Kesehatan Anak, remaja berada pada kurun usia 10-18 tahun. Sedangkan menurut Badan Kependudukan dan Keluarga Berencana Nasional (BKKBN) disebutkan bahwa remaja berada pada kurun usia 15-24 tahun dan belum menikah (Badan Pusat Statistik, 2016; BKKBN, 2017).

\subsection{Masalah Pokok Perilaku Berisiko pada Pemuda}

Pada bagian ini penulis akan membahas apa saja tantangan dan halangan yang akan dihadapi para pemuda dan menjadi ancaman bagi kelangsungan hidup mereka ke depan. Beberapa tantangan yang akan diangkat misalnya perilaku seksual berisiko pada pemuda, perilaku perundungan dan perilaku penyalahgunaan NAPZA.

\subsubsection{Perilaku Seksual Berisiko}

Perilaku seksual berisiko pada pemuda merupakan salah satu isu utama yang menjadi fokus perhatian dalam rencana pemerintah jangka menengah nasional (RPJMN) tahun 2020-2024, dan menjadi bagian dari salah satu strategi peningkatan kualitas pemuda yaitu pencegahan perilaku berisiko pada pemuda. Berdasarkan survei demografi dan kesehatan: kesehatan reproduksi remaja 2017 (SDKI), dilaporkan bahwa $8 \%$ pria dan $2 \%$ wanita usia 15-24 tahun pernah melakukan hubungan seksual, dan usia 17 tahun merupakan umur tertinggi baik pria maupun wanita melakukan hubungan seksual tersebut dengan angka sebesar 19\% (BKKBN, 2017).

Hal ini menunjukkan bahwa sebagian kecil pemuda telah melakukan perilaku seksual berisiko pada usia dini yaitu mulai usia 15 tahun.

Pada sisi lain, jumlah kasus HIV di Indonesia terus meningkat dari tahun ke tahun dengan jumlah 50.282 kasus HIV dan 7.036 kasus AIDS pada tahun 2019, dengan Jawa Timur sebagai provinsi tertinggi jumlah infeksi HIV yang dilaporkan pada tahun 2019 yaitu sebanyak 8.935 kasus (Pusat Data dan Informasi Kementerian Kesehatan Republik Indonesia, 2020).

Penambahan jumlah kasus HIV dari tahun ke tahun menurut hemat penulis dapat diartikan sebagai dampak dari perilaku seksual berisiko yang telah dimulai para pemuda pada usia 15 tahun, sebagaimana dijelaskan di atas.

\subsubsection{Perilaku Perundungan}

Salah satu data perilaku berisiko pada pemuda yaitu perundungan dapat dilihat dari Survei Nasional Pengalaman Hidup Anak dan Remaja (SNPHAR) 2018 yang dilakukan oleh Kementerian PPPA bekerja sama dengan BPS, STKS, PKMK UGM dan PUSKAPA UI yang menyatakan bahwa $12-15 \%$ anak laki-laki dan perempuan usia 13-17 tahun pernah mengalami kekerasan melalui media daring dalam 12 bulan terakhir (Purwanto, 2020; UNICEF, 2020). Sementara itu berdasarkan data hasil riset Programme for International Students Assessment (PISA) 2018 menunjukkan murid yang mengaku pernah mengalami perundungan (bullying) di Indonesia sebanyak 41,1\%. Angka murid korban perundungan ini jauh di atas rata-rata negara anggota OECD yang hanya sebesar 22,7\% (Jayani, 2019).

\subsubsection{Perilaku Penyalahgunaan NAPZA}

Perilaku berisiko pada pemuda selanjutnya adalah penyalahgunaan narkotika, psikotropika, dan zat adiktif lainnya (NAPZA), di mana pemuda Indonesia memiliki persoalan narkotika yang bersifat polydrug use yaitu bereksperimen dengan berbagai zat psikoaktif (85\% pengguna memakai lebih dari $2-15$ jenis zat) dan kebanyakan menyalahgunakannya di bawah umur 20 tahun (BNN, 2019b, hlm. 1-70). Prevalensi penyalahgunaan narkoba sendiri bervariasi dari 
kelompok umur yang ada, yaitu usia $<24$ tahun sebesar $1,8 \%$ dan usia 24-49 tahun sebesar 3,1\%, yang diartikan mayoritas penyalahgunaan narkoba berusia produktif (BNN, 2019a). Persentase pria dan wanita usia 15-24 tahun yang mengonsumsi obat terlarang menurut cara penggunaannya yaitu pria sebesar 5\% (2\% dihisap dan 3\% diminum/ditelan) sedangkan untuk wanita kurang dari $1 \%$ (BKKBN, 2017).

Dalam pemahaman umum, perilaku penyalahgunaan NAPZA oleh pemuda tidak lepas dari pengaruh perilaku berisiko yang sangat dasar yaitu perilaku merokok (Afifiyah, 2019; BNN, 2013; Maharani, 2017). Distribusi persentase pria dan wanita belum kawin usia 15-24 tahun yang merokok yaitu pada pria usia 15-19 tahun sebesar 47,6\% sedangkan usia 20-24 tahun sebesar 67,1\% dan pada wanita usia 15-19 tahun sebesar 0,8\% sedangkan usia 20-24 tahun sebesar 1,4\% (BKKBN, 2017). Persentase tertinggi umur pertama kali merokok pada pemuda usia 15-24 tahun dan belum kawin adalah pada pria berumur kurang dari 13 tahun sebesar 24,2\% dan pada wanita berumur kurang dari 13 tahun juga sebesar 37,6\% (BKKBN, 2017).

Tantangan selanjutnya yang dihadapi para pemuda selain perilaku berisiko di atas adalah angka pengangguran di kalangan mereka. Tingkat partisipasi angkatan kerja (TPAK) pemuda pada tahun 2020 adalah sebesar $61,31 \%$, dengan perbandingan TPAK pemuda laki-laki sebesar 73,9\% dan TPAK pemuda perempuan sebesar 48,46\% (Badan Pusat Statistik, 2020b). Masih dalam laporan yang sama juga, untuk tingkat pengangguran terbuka pemuda pada tahun 2020 adalah sebesar 15,23\%. Persentase tersebut dapat diartikan di antara 100 pemuda terdapat 15 pemuda tidak bekerja dan sedang mempersiapkan usaha atau mencari pekerjaan. Catatan lain yang harus diperhatikan adalah fakta adanya $21,08 \%$ pemuda usia 16-18 tahun yang sudah bekerja. Sesuai dengan peraturan yang ada yaitu Undang-Undang 23 Tahun 2002 tentang Perlindungan Anak, usia dimaksud masih dalam usia anak-anak yang seharusnya terbebas dari kewajiban untuk bekerja, dan lebih menitikberatkan pada unsur pendidikan (Badan Pusat Statistik, 2020a; Diprose dkk., 2019; UNICEF, 2020).

\section{Metode}

Tulisan ini menggunakan pendekatan kualitatif yaitu dengan membahas dan mencari solusi serta memberikan rekomendasi dengan jalan masuk ke dalam permasalahan atau isu yang diangkat. Bermula dari pemilihan kerangka pikir kemudian memunculkan asumsi dan hipotesis untuk diuji hubungan sebab akibatnya. Pendekatan yang sedikit banyak bersifat pemikiran individu, interpretasi pemahaman dan proses yang dipilih (Given, 2008; Wijaya, 2019).

Pendekatan kualitatif dipilih karena kedekatan penulis dengan tema atau kasus tulisan sehingga memudahkan terjun dan menyelami apa yang menjadi pokok bahasan. Di samping hal tersebut, alasan objektif lainnya adalah untuk pendekatan kuantitatif nantinya akan digunakan penulis pada tindak lanjut hasil penelitian sekarang ini, sehingga akan saling melengkapi satu sama lain. Hubungan utama pendekatan kualitatif dengan perilaku berisiko pada pemuda adalah karena objek yang diamati adalah perilaku manusia yang menjadi fenomena di lapangan sehingga memerlukan pengetahuan mendalam atas isu tersebut dan terbuka untuk kemungkinan perubahan selama proses analisis nantinya.

Jenis penelitian yang digunakan dalam tulisan ini adalah studi kasus terhadap tantangan yang dihadapi para pemuda saat ini. Studi kasus ini diharapkan mampu menjawab urgensi strategi pencapaian target peningkatan kualitas pemuda yang merupakan fondasi pembangunan SDM berkualitas (Sudrajat \& Moha, 2019) sebagaimana termaktub di dalam RPJMN 2020-2024. Harapannya hasil tulisan penelitian ini nantinya dapat menjadi contoh dan digunakan secara umum dalam isu atau tema lainnya yang bermaksud menguji ketahanan strategi yang ada dengan konteks kasus yang ada di lapangan.

Metode pengumpulan data yang digunakan adalah studi dokumen. Data yang dikumpulkan bersifat data sekunder dan kualitatif berdasarkan hasil dokumentasi yang ada seperti artikel dari jurnal, buku, media massa, dan dokumen hukum serta dokumen lain yang dianggap perlu (Denzin \& Lincoln, 2011; Gunawan, 2013, hlm. 143). Metode ini memiliki keunggulan yaitu tidak terbatas ruang dan waktu sehingga penulis dapat mendapatkan referensi yang cukup luas dan mendalam dalam membedah kasus yang ada. 
Berdasarkan data yang sudah dikumpulkan, maka penulis terus melakukan analisis dari awal sampai akhir penulisan. Dengan model induktif, penulis mencoba untuk menulis analisis dari detail data yang diperoleh dengan mengharapkan hasil keluarannya yang umum dapat menjadi generalisasi dalam berbagai kasus lain yang ada, tentunya selama memiliki konteks, ciri dan kriteria yang sama atau setidaknya mirip.

\section{Hasil dan Pembahasan}

Peraturan Presiden Nomor 18 Tahun 2020 tentang Rencana Pembangunan Jangka Menengah Nasional (RPJMN) merupakan dokumen induk perencanaan nasional untuk periode 5 tahun yaitu dari tahun 2020-2024. RPJMN berisi tentang visi dan misi serta program dari Presiden terpilih hasil pemilihan umum yang memuat strategi pembangunan nasional sampai dengan kerangka regulasi dan kerangka pendanaan indikatif.

Tema tulisan yaitu peningkatan kualitas pemuda, khususnya melalui pencegahan perilaku berisiko pada pemuda, masuk ke dalam Prioritas Nasional 3 Meningkatkan SDM berkualitas dan berdaya saing, khususnya di Kegiatan Prioritas 3 Peningkatan kualitas pemuda, Proyek Prioritas 1-3 yaitu penguatan kapasitas kelembagaan dan koordinasi lintas sektor layanan kepemudaan, pencegahan perilaku berisiko serta partisipasi aktif sosial dan politik pemuda.

Terkait isu kewirausahaan pada pemuda, isu ini masuk juga ke dalam Prioritas Nasional 1 Memperkuat ketahanan ekonomi untuk pertumbuhan yang berkualitas di Kegiatan prioritas 1 Peningkatan penciptaan startup dan peluang usaha, Proyek Prioritas 4 Pelatihan kewirausahaan. Di mana Presiden telah menginstruksikan kepada semua jajaran pemerintah untuk menyukseskan program penciptaan startup ini khususnya kepada para pemuda dalam menjawab perkembangan teknologi yang ada saat ini di jaman revolusi industri 4.0.

Di dalam Rencana Kerja Pemerintah tahun 2021 telah ditetapkan beberapa rincian output atau $\mathrm{RO}$ dari masing-masing proyek prioritas di atas, misalnya dalam pelatihan kewirausahaan target dari RO yang ada adalah 5.000 orang pemuda terfasilitasi sebagai kader kewirausahaan, RO dari pemuda kader yang terfasilitasi dalam peningkatan wawasan kebangsaan dan anti paham radikalisme memiliki target sebanyak 3.400 orang pemuda, dan RO sentra kewirausahaan pemuda yang terfasilitasi pengembangan kewirausahaan dengan target sebanyak 34 lembaga.

Secara lebih spesifik, strategi peningkatan kualitas pemuda mencakup 3 hal sebagaimana tertera dalam RPJMN 2020-2024 yaitu 1) Penguatan kapasitas kelembagaan, sistem koordinasi strategi lintas pemangku kepentingan, serta pengembangan peran dunia usaha dan masyarakat dalam menyelenggarakan pelayanan kepemudaan yang terintegrasi, termasuk memfasilitasi ruang-ruang kreasi positif bagi pemuda, 2) Peningkatan partisipasi aktif sosial dan politik pemuda di antaranya melalui peran pemuda di forum internasional, pertukaran pemuda, dan keikutsertaan dalam pelestarian lingkungan, dan 3) Pencegahan perilaku berisiko pada pemuda, termasuk pencegahan atas bahaya kekerasan, perundungan, penyalahgunaan NAPZA, minuman keras, penyebaran penyakit HIV/AIDS dan penyakit menular seksual.

Strategi pencegahan perilaku berisiko pada pemuda, termasuk pencegahan atas bahaya kekerasan, perundungan, penyalahgunaan NAPZA, minuman keras, penyebaran penyakit HIV/AIDS dan penyakit menular seksual.

Setidaknya ada dua proyek prioritas di dalam RPJMN terkait dengan strategi penyalahgunaan NAPZA yaitu pertama, Proyek Prioritas Pencegahan perilaku berisiko dengan dua proyek yaitu 1). Fasilitasi pemuda kader dalam peningkatan penanggulangan penyalahgunaan narkoba dengan indikator jumlah pemuda kader yang difasilitasi, dan 2). Fasilitasi pelaksanaan jambore nasional dengan indikator jumlah keikutsertaan provinsi. Kedua, Proyek Prioritas Pemanfaatan ruang publik untuk pertukaran ide dan gagasan di kalangan pelajar, mahasiswa dan pemuda lintas budaya, lintas agama dan lintas suku bangsa, dengan judul proyek fasilitasi pemuda kader dalam peningkatan penanggulangan penyalahgunaan narkoba, indikator proyek ini adalah jumlah pemuda kader yang difasilitasi.

Selain melalui proyek prioritas di dalam RPJMN, pemerintah juga memberikan payung hukum bagi pelaksanaan strategi ini di lapangan yaitu melalui penyusunan regulasi terkait. Salah satu regulasi 
pendukung strategi pencegahan perilaku berisiko pada pemuda ini yaitu Instruksi Presiden Nomor 2 Tahun 2020 tentang Rencana Aksi Nasional Pencegahan dan Pemberantasan Penyalahgunaan dan Peredaran Gelap Narkotika dan Prekursor Narkotika (P4GN) Tahun 2020-2024.

Sedangkan untuk pencegahan atas bahaya kekerasan dan atau perundungan setidaknya ada beberapa proyek prioritas yang disebutkan di dalam RPJMN. Pertama, proyek prioritas pengembangan budaya belajar dan lingkungan sekolah yang menyenangkan dan bebas dari kekerasan (bullying free school environment) dengan proyek siswa yang mendapatkan pendidikan karakter bangsa di level SD, SMP, SMA dan pendidikan khusus, dan proyek peningkatan kapasitas personal dan sosial sebagai agen perubahan dengan indikator anak remaja yang mengikuti peningkatan kapasitas. Kedua, proyek prioritas penjaminan pemenuhan hak anak secara universal melalui proyek pencegahan kekerasan terhadap anak berbasis sekolah, dengan indikator jumlah daerah yang difasilitasi. Ketiga, proyek prioritas perlindungan anak dari tindak kekerasan, eksploitasi, penelantaran dan perlakuan salah lainnya, dengan berbagai macam proyek seperti provinsi yang difasilitasi dalam pelaksanaan kampanye perlindungan anak dari kekerasan dengan indikator jumlah provinsi yang difasilitasi.

Sementara itu terkait dengan pencegahan penyebaran penyakit HIV/AIDS dan penyakit menular seksual berada di bawah proyek prioritas pengendalian penyakit menular dengan indikator persentase orang dengan HIV/ AIDS (ODHA) baru ditemukan yang memulai pengobatan ARV dan proyek penyediaan obar dan perbekalan kesehatan program pencegahan dan pengendalian HIV/AIDS dengan indikator persentase kabupaten/kota dengan ketersediaan obat HIV/AIDS.

\subsection{Analisis Teori Pencegahan}

Teori Pencegahan yang digunakan dalam tulisan ini mengedepankan pada aspek dasar seperti aspek inventarisasi risiko dan dampak dalam melakukan intervensi, aspek modalitas sosial seperti sosialisasi dan edukasi, serta aspek identifikasi sebab/faktor psikologis dan sosiologis, dengan hasil analisis sebagai berikut:

Apabila dilihat dari aspek inventarisasi risiko dan dampak dari intervensi, maka strategi pencegahan perilaku berisiko ini cukup logis untuk digunakan oleh pemerintah dalam rangka peningkatan kualitas pemuda. Strategi di RPJMN tersebut mencoba merangkum semua perilaku berisiko yang ada pada pemuda seperti tentang narkoba, bahaya kekerasan, perundungan, minuman keras, penyebaran penyakit HIV/AIDS dan penyakit menular seksual. Hanya saja catatan utama dari strategi yang dijabarkan melalui proyek prioritas, proyek dan indikator yang ada terkesan masih berkutat pada aspek kuantitas saja seperti jumlah daerah, jumlah kader, sementara kualitas pencegahan perilaku berisiko yang ada belum terlihat.

Dari aspek modalitas sosial, proyek-proyek di atas bisa jadi merupakan salah satu wadah sosialisasi dan edukasi kepada para pemuda terhadap perilaku berisiko. Namun hal tersebut juga kemudian menjadi catatan tersendiri bagi penyelenggara negara di mana kualitas sosialisasi dan edukasi yang diharapkan masih sangat terbatas cakupannya yaitu hanya pada target yang ditentukan saja. Padahal dari aspek modalitas, sosialisasi dan edukasi merupakan langkah utama yang harus dijalankan agar para pemuda tidak terjerumus pada perilaku berisiko dan kemudian kita bergerak pada ranah pengobatan, bukan pencegahan lagi.

Aspek ketiga yang juga harus disoroti adalah belum cukup terwadahinya identifikasi sebab psikologis dan sosial dalam strategi pencegahan perilaku berisiko di atas termasuk melalui proyek prioritas dan proyek yang disusun serta target dari masing-masing proyek. Terjerumusnya para pemuda dalam perilaku berisiko yang disebutkan harus dikaji secara maksimal melalui program kegiatan dan proyek prioritas yang ada sehingga kita bisa mengetahui sebab dan akar permasalahan yang dihadapi mereka. Dengan diketahuinya sebab dan akar permasalahan mereka baik dari sisi psikologis maupun sisi sosial maka pemerintah akan semakin mudah dalam merumuskan kebijakan intervensi di lapangan untuk mencegah perilaku berisiko pada pemuda ke depan.

Realita maraknya perilaku seksual berisiko pada pemuda seperti maraknya istilah open booking online atau open $B O$ di media sosial harus dicarikan alasan dan sebab asal muasalnya dan ini harus menjadi fokus perhatian pemerintah ke depan. Beberapa alasan yang dijadikan dasar bagi terjadi perilaku tersebut adalah kemiskinan sehingga mereka menghalalkan segala cara 
untuk memenuhi kebutuhannya, gaya hidup sebagai dampak negatif dari kemajuan teknologi informasi yang tidak dibarengi dengan literasi digital yang baik, serta lemahnya ketahanan keluarga para pemuda atau remaja tersebut seperti karena persoalan perceraian orang tua (Singarimbun, 2019; Syukur, 2014; Ulfiah \& Hannah, 2018).

\subsection{Analisis Teori Perilaku}

Dalam konteks tulisan ini, perilaku berisiko pada pemuda akan sangat tergantung dari banyak perilaku yang melingkupinya misalnya perilaku dalam keluarga, perilaku teman sebaya, dan perilaku dari tontonan yang mereka lihat baik dari media sosial, cetak, maupun media lainnya termasuk juga pendidikan.

Dalam konteks ini, tindakan pemerintah melalui intervensi program kegiatan dan penyusunan regulasi hukum misalnya, merupakan contoh perilaku yang melingkupi isu pencegahan perilaku berisiko pada pemuda di lapangan. Perilaku pemerintah tersebut baik yang dilakukan melalui saluran resmi dari kementerian atau lembaga maupun melalui saluran umum seperti di media massa dan sosial merupakan salah satu faktor dalam pencapaian target pencegahan perilaku berisiko pada pemuda ini.

Dari sisi pencegahan penyalahgunaan narkoba, proyek fasilitasi kader pencegahan narkoba dan fasilitasi pelaksanaan jambore nasional dapat dilihat sebagai wahana penciptaan ruang-ruang pertukaran perilaku antar pemuda di lapangan. Hasil dari fasilitasi kader pencegahan narkoba diharapkan bahwa para kader akan dapat memberikan contoh perilaku bagi para rekan sebayanya untuk berperan serta secara aktif dalam rangka mencegah penyalahgunaan narkoba, baik untuk dirinya sendiri maupun untuk lingkungannya.

Terkait dengan pencegahan perundungan sebagaimana disebutkan dalam proyek prioritas yang telah disebutkan di depan, dari kacamata teori perilaku hal ini sudah sangat sesuai mengingat tingginya angka perundungan di kalangan siswa sehingga pengembangan budaya belajar yang menyenangkan dan bebas dari kekerasan sangat tepat untuk dilakukan demi lahirnya perilaku-perilaku baru yang lebih sesuai etika pergaulan. Salah satu proyek yang ada misalnya proyek pendidikan karakter bangsa dan peningkatan kapasitas personal dan sosial pada para siswa sangat berguna dalam membangun fondasi perubahan perilaku mereka yang sudah terpapar perilaku perundungan baik secara verbal maupun non verbal, baik secara langsung maupun melalui media sosial yang ada. Dengan pendidikan karakter bangsa, maka para siswa akan terbangun kesadarannya akan pentingnya etika pergaulan dan nilai-nilai moral lain yang menjadi budaya bangsa seperti tepo salira atau saling menghargai satu sama lain.

Dalam hal pencegahan perilaku seksual berisiko pada pemuda, pemerintah telah menetapkan proyek prioritas yang berusaha mengendalikan pertambahan angka orang dengan HIV/AIDS (ODHA) baru di tiap waktunya. Pengendalian pertambahan angka ODHA akan sangat terkait dengan adanya pengendalian perilaku seksual berisiko di mana dari lini pencegahan harus memaksimalkan faktor-faktor sosialisasi dan edukasi kepada para pemuda, melalui beragam media atau wahana yang ada, khususnya sesuai dengan kemajuan teknologi maka sosialisasi dan edukasi di ranah media sosial harus diutamakan. Proyek ketersediaan obat antiretroviral (ARV) kemudian seharusnya hanya menjadi pelengkap dari proyek pengendalian saja, sebagai bentuk tanggung jawab pemerintah untuk tidak lepas tangan pada mereka yang sudah terlanjur terpapar. Ke depan, apabila proyek pengendalian telah berhasil, maka proyek pengadaan obat ARV kemudian hanya untuk memfasilitasi mereka yang sudah terpapar saja bukan dari hasil penambahan angka ODHA baru.

\subsection{Analisis Teori Risiko}

Dalam konteks pencegahan perilaku berisiko pada pemuda, konsep risiko ini lebih merujuk pada pendapat utama yang menyatakan bahwa risiko mendatangkan konotasi negatif dan tidak menguntungkan bagi organisme. Risiko berisi kemungkinan-kemungkinan yang terjadi dari sebuah tindakan atau aksi dan mengandung ketidakpastian yang mengancam pencapaian tujuan dan sasaran. Bagi penulis sendiri, tidak melihat dan meyakini satu pun sisi positif yang menguntungkan dari tingginya angka kesakitan para pemuda dikarenakan rokok, NAPZA, seks bebas (di luar nikah) dan perundungan yang ada.

Berdasarkan risiko-risiko yang ada pada pemuda, strategi pencegahan perilaku berisiko pada pemuda 
sebenarnya sudah sangat pas dan tepat untuk diimplementasikan melalui program dan kegiatan yang ada. Hanya saja, tidak semua proyek yang dilakukan di lapangan berdasarkan proyek prioritas yang ada cukup andal dalam mendukung pencapaian target dimaksud. Beberapa catatan dari pendekatan teori risiko terhadap proyek yang ada misalnya dalam proyek pelaksanaan jambore nasional. Apakah kemudian dengan pelaksanaan jambore ini, target penurunan angka perilaku berisiko pada pemuda dapat diwujudkan, misalnya dengan adanya pelaksanaan jambore nasional tersebut maka dapat menurunkan angka penyalahgunaan narkoba atau perilaku seksual berisiko karena jambore meminimalisir kemungkinan dari ketidakpastian perilaku pemuda di lingkungannya.

Catatan lain adalah dalam proyek pendidikan karakter bangsa dan peningkatan kualitas personal dan sosial pemuda. Apakah melalui proyek tersebut para pemuda dapat diminimalisir perilakunya untuk terjerumus pada perilaku berisiko seperti penyalahgunaan narkoba dan perundungan. Sudah seharusnya pemerintah dapat dipastikan bahwa dengan banyaknya faktor kemungkinan yang ada, maka proyek pendidikan karakter bangsa harus berhasil menyasar turunnya angka risiko sebagai hasil kuatnya nilai internal para pemuda untuk menolak semua pilihan kemungkinan negatif yang ada di hadapan mereka. Pendidikan karakter bangsa ini harus bisa mewujudkan adanya ketahanan diri para pemuda dalam menghadapi semua ketidakpastian yang negatif dan mengancam cita-cita mereka.

\section{Kesimpulan}

Strategi peningkatan kualitas pemuda melalui pencegahan perilaku berisiko pada pemuda sebagaimana tertuang di dalam RPJMN 2020—2024 secara umum sudah memenuhi kriteria analisis berdasarkan teori pencegahan, teori perilaku dan teori risiko yang diuraikan di awal pembahasan. Hanya saja, ketika strategi dimaksud diejawantahkan melalui proyek-proyek turunan dari proyek prioritas yang ada, simpulan analisis terhadap strategi dimaksud menyatakan belum 100\% tepat guna dan tepat hasil dalam mencegah perilaku berisiko pada pemuda.

Hasil analisis menyimpulkan masih terdapat catatan khusus seperti: 1). proyek yang ditentukan masih berkutat pada aspek kuantitas saja seperti jumlah daerah, jumlah kader, sementara kualitas pencegahan perilaku berisiko yang ada belum terlihat, 2). kualitas sosialisasi dan edukasi yang diharapkan masih sangat terbatas cakupannya yaitu hanya pada target yang ditentukan saja, padahal jangkauan pemuda masih sangat luas di lapangan, dan 3). belum adanya proyek yang mengkaji secara khusus sebab dan akar permasalahan keterlibatan para pemuda baik dari sisi psikologis maupun sisi sosial dalam perilaku berisiko padahal hal ini sangat krusial.

\subsection{Saran dan Rekomendasi}

Dalam rangka pencapaian target pembangunan SDM berkualitas melalui peningkatan kualitas pemuda dengan strategi pencegahan perilaku berisiko pada pemuda, berdasarkan analisis yang didapatkan di depan, berikut beberapa saran dan rekomendasi yang ditawarkan penulis dalam rangka memperkuat pencegahan:

Pertama, meningkatkan sosialisasi dan edukasi kepada para pemuda tentang risiko-risiko dari perilaku yang mereka pilih termasuk konsekuensi yang menunggu. Dengan pemberian sosialisasi dan edukasi yang cukup, diharapkan para pemuda akan memiliki pemahaman yang baik terhadap pilihan-pilihan perilaku yang akan ditempuh beserta risiko yang menunggu sebagai konsekuensi logisnya. Pemuda yang memiliki pemahaman baik terhadap semua perilaku berisiko dan konsekuensinya maka akan memiliki ketahanan yang baik dari ancaman-ancaman yang menghadang mereka di depan sebagai para generasi penerus bangsa. Rekomendasi utama adalah penyusunan proyek-proyek yang lebih komprehensif dalam penguatan sosialisasi dan edukasi kepada para pemuda sehingga mereka memiliki ketahanan diri yang cukup.

Kedua, memperkuat identifikasi faktor-faktor yang mempengaruhi para pemuda melakukan perilaku berisiko. Identifikasi ini sangat diperlukan bagi para pembuat kebijakan dalam merumuskan kebijakan yang akan dipilih dalam rangka pencapaian target peningkatan kualitas pemuda. Tanpa adanya identifikasi yang tepat, baik dan benar, maka akan memunculkan kemungkinan kesalahan pemilihan program kegiatan sebagai bentuk kebijakan yang ada. Identifikasi ini seharusnya dimulai dari hal yang paling dekat dengan para pemuda misalnya identifikasi alasan pribadi, 
permasalahan keluarga, lingkungan sosial dan sebagainya. Rekomendasi utama yang ditawarkan adalah penyusunan program kegiatan identifikasi faktor yang mempengaruhi para pemuda melakukan perilaku berisiko sebagai dasar penyusunan kebijakan yang tepat, baik dan benar dalam peningkatan kualitas pemuda.

Ketiga, penguatan literasi digital para pemuda sebagai bagian dari penyelarasan dengan perkembangan teknologi dan revolusi industri 4.0. Penguatan literasi digital ini akan membawa para pemuda pada sebuah kondisi yang lebih melek teknologi dengan tetap memiliki etika yang baik di media sosial termasuk budaya dalam bermedia digital. Dengan memiliki literasi digital yang baik, para pemuda juga akan dapat memilah konten mana saja yang layak untuk dikonsumsi dan yang harus dihindari. Rekomendasi utama yang ditawarkan adalah penguatan literasi digital kepada para pemuda dengan menggunakan pendekatan yang lebih kekinian, sehingga mereka tidak akan antipati terhadap program yang ada dan justru mendukung dengan penuh daya kreativitas.

\section{Ucapan Terima Kasih}

Terima kasih saya sampaikan kepada segenap pimpinan di Deputi Bidang Koordinasi Peningkatan Kualitas Anak, Perempuan, dan Pemuda dan khususnya rekan kerja di Asisten Deputi Pemberdayaan Pemuda yang telah memberikan dukungan dalam penyelesaian tulisan ini.

\section{Referensi}

Afifiyah, S. (2019, Maret 5). Rokok Pintu Gerbang Menuju Narkoba Benarkah? Tagar.id. https://www.tagar.id/rokok-pintu-gerbangmenuju-narkoba-benarkah

Almer, B. (1967). Modern General Risk Theory. ASTIN Bulletin, 4(2), 136-169. https://doi.org/10.1017/S0515036100010710

Badan Pusat Statistik. (2016). Kemajuan yang Tertunda: Analisis Data Perkawinan Usia Anak di Indonesia. BPS. https://www.bps.go.id/ publication/2016/01/04/aa6bb91f9368be69e00d036d/kemajuanyang-tertunda--analisis-data-perkawinan-usia-anak-diindonesia.html

Badan Pusat Statistik. (2020a). Booklet Survei Angkatan Kerja Nasiona Agustus 2020. BPS. https://www.bps.go.id/publication/2020/12/23/ d8b9a75ce826ddafbddb9657/booklet-survei-angkatan-kerjanasional-agustus-2020.htm

Badan Pusat Statistik. (2020b). Statistik Pemuda Indonesia 2020. BPS h t t p s : / / w w w. b p s.go. i d / p u b I i c a t i o n / 2020/12/21/4a39564b84a1c4e7a615f28b/statistik-pemudaindonesia-2020.html

Badan Pusat Statistik. (2021). Hasil Sensus Penduduk 2020. BPS. https:// www.bps.go.id/pressrelease/2021/01/21/1854/hasil-sensus penduduk-2020.html

BKKBN. (2017). Survei Demografi dan Kesehatan 2017. BKKBN.

BNN. (2013, Mei 6). Rokok Gerbang Narkoba. Badan Narkotika Nasional Republik Indonesia. https://bnn.go.id/rokok-gerbang-narkoba/

BNN. (2019a). Infografis Survei Prevalensi Penyalahgunaan Narkoba Tahun 2019. BNN.
BNN. (2019b). Riset Kesehatan Dampak Penyalahgunaan Narkoba 2019. BNN.

Campbell Institute. (2016). Risk Perception: Theories, Strategies, and Nex Steps. Campbell Institute.

Denzin, N. K., \& Lincoln, Y. S. (2011). Introduction: The Discipline and Practice of Qualitative Research. In N. K. Denzin \& Y. S. Lincoln (Ed.) The Sage Handbook of Qualitative Research. Sage Publications Ltd.

Diprose, R., McRae, D., \& Hadiz, V. R. (2019). Two Decades of Reformasi in Indonesia: Its Illiberal Turn. Journal of Contemporary Asia, 49(5), 1-22. https://doi.org/10.1080/00472336.2019.1637922

Direktorat Jenderal Kebudayaan Kemendikbud. (2016). Merayakan Indonesia Raya.

Foulcher, K. (2000). Sumpah Pemuda: the making and meaning of a symbol of Indonesian nationhood. Asian Studies Review, 24(3), 377-410. https://doi.org/10.1080/10357820008713281

Freedman, A. L. (2017). Lee, Doreen: Activist Archives - Youth Culture and the Political Past in Indonesia. Anthropos, 112(2), 685-686. https:// doi.org/10.5771/0257-9774-2017-2-685

Freeman, R. (1995). Prevention and Government: Health Policy Making in the United Kingdom and Germany. Journal of Health Politics, Policy and Law, 20(3), 745-765. https://doi.org/ 10.1215/03616878-20-3-745

Geason, S., \& Wilson, P. R. (1988). Crime Prevention: Theory and Practice. Australian Institute of Criminology.

Given, L. M. (Ed.). (2008). The SAGE Encyclopedia of Qualitative Research Methods. Sage Publications, Inc.

Goebel, Z. (2013). The idea of ethnicity in Indonesia. In Tilburg Papers in Culture Studies.

Gough, I. (2013). Understanding prevention policy: a theoretica approach. In The prevention papers. https://eprints.Ise.ac.uk/47951/

Gunawan, I. (2013). Metode Penelitian Kualitatif. Bumi Aksara.

Hanafi, M. M. (2014). Risiko, Proses Manajemen Risiko, dan Enterprise Risk Management. In Manajemen Risiko.

Jayani, D. H. (2019, Desember 12). PISA: Murid Korban "Bully" di Indonesia Tertinggi Kelima di Dunia. Databoks. https:// databoks.katadata.co.id/datapublish/2019/12/12/pisa-muridkorban-bully-di-indonesia-tertinggi-kelima-di-dunia

Kaloeti, D. V. S., Manalu, R., Kristiana, I. F., \& Bidzan, M. (2021). The Role of Social Media Use in Peer Bullying Victimization and Onset of Anxiety Among Indonesian Elementary School Children. Frontiers in Psychology, 12(April), 1-10. https://doi.org/10.3389/ fpsyg.2021.635725

Maag, J. W. (2014). Persistent Issues in Behavioral Theory and Practice. In L. Florian (Ed.), The SAGE Handbook of Special Education: Two Volume Set. SAGE Publications Ltd. https://doi.org/ 10.4135/9781446282236.n19

Maharani, D. (2017, Maret 7). Rokok Jadi Pintu Gerbang Memakai Narkoba. Kompas.com. https://health.kompas.com/read/

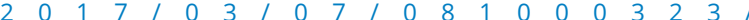
rokok.jadi.pintu.gerbang.memakai.narkoba

Martin-Löf, A., \& Sköllermo, A. (2011). Notes on Risk Theory.

Massetti, G. M., \& David-Ferdon, C. (2016). Preventing Violence Among High-Risk Youth and Communities with Economic, Policy, and Structural Strategies. MMWR Supplements, 65(1), 57-60. https:// doi.org/10.15585/mmwr.su6501a9

Meško, G., \& Muršič, M. (Ed.). (2003). Crime Prevention - Theory, Practice and Dilemmas: A Book of Conference Abstracts of the Second Slovene Criminological Conference. The Institute of Criminology at the Faculty of Law-Ljubljana, College of Police and Security StudiesLjubljana, Slovenia Society of Criminal Law and Criminology.

Paauw, S. (2009). One Land, One Nation, One Language: An Analysis of Indonesia's National Language Policy (University of Rochester Working Papers in the Language Sciences, Vol. 5, Nomor 1). 
Pakpahan, M., Siregar, D., Susilawaty, A., Tasnim, Mustar, Ramdany, R., Manurung, E. I., Sianturi, E., Tompunu, M. R. G., Sitanggang, Y. F., \& M., M. (2021). Promosi Kesehatan dan Perilaku Kesehatan. Yayasan Kita Menulis.

Permatasari, D., \& Suprayitno, E. (2020). Implementasi Kegiatan Pendidik Sebaya dan Konselor Sebaya dalam Upaya Pencegahan Triad KRR di Pusat Informasi dan Konseling Remaja. Jurnal Ners dan Kebidanan Uournal of Ners and Midwifery), 7(1), 143-150. https://doi.org/ 10.26699/jnk.v7i1.art.p143-150

Plackett, R. L. (1969). Risk Theory. Transactions of the Faculty of Actuaries, 32, 337-362. https://doi.org/10.1017/s0071368600004985

Purwanto, A. (2020, Juli 27). Potret Pemenuhan Hak-Hak Anak Indonesia Terkini. Kompaspedia. https://kompaspedia.kompas.id/baca/ paparan-topik/potret-pemenuhan-hak-hak-anak-indonesia

Pusat Data dan Informasi Kementerian Kesehatan Republik Indonesia. (2015). Situasi Kesehatan Reproduksi Remaja. Pusat Data dan Informasi Kementerian Kesehatan Republik Indonesia. https:// pusdatin.kemkes.go.id/article/view/15090700003/situasikesehatan-reproduksi-remaja.html

Pusat Data dan Informasi Kementerian Kesehatan Republik Indonesia. (2020). Infodatin HIV. In Pusat Data dan Informasi Kementerian Kesehatan Republik Indonesia. Pusat Data dan Informasi Kementerian Kesehatan Republik Indonesia. https:// pusdatin.kemkes.go.id/article/view/20111200002/infodatinhiv.html

Rahmat. (2003). Sumpah Pemuda: Antara Idealisme dan Realisme Pendidikan Politik. Kependidikan Is/am, 1(1), 58-69. http://digilib.uinsuka.ac.id/id/eprint/8581

Rinta, L. (2015). Pendidikan Seksual dalam Membentuk Perilaku Seksual Positif pada Remaja dan Implikasinya terhadap Ketahanan Psikologi Remaja. Jurnal Ketahanan Nasional, 21(3), 163-174. https:/ /doi.org/10.22146/jkn.15587

Sari, E. P., \& Rizqi, Y. F. (2019). Smith's Nationalism Perspective in the Indonesian History Textbooks on The Youth Oath 1928 Narrative. Historika, 22(2), 97-114. https://doi.org/10.20961/ historika.v22i2.38075

Savitri, W. C., \& Listiyandini, R. A. (2017). Mindfulness dan Kesejahteraan Psikologis pada Remaja. Psikohumaniora: Jurnal Penelitian Psikologi, 2(1), 43-59. https://doi.org/10.21580/pjpp.v2i1.1323

Sebastian, L. C., Chen, J., \& Syailendra, E. A. (2014). Pemuda Rising: Why Indonesia Should Pay Attention to its Youth. In RSIS Monograph No.
29. S. Rajaratnam School of International Studies. https:// www.rsis.edu.sg/rsis-publication/idss/pemuda-rising-whyindonesia-should-pay-attention-to-its-youth/

Peraturan Pemerintah Nomor 60 Tahun 2008 tentang Sistem Pengendalian Intern Pemerintah, (2008).

Silverman, M. M. (2003). Theories of Primary Prevention and Health Promotion. In Encyclopedia of Primary Prevention and Health Promotion (hlm. 27-42). Springer US. https://doi.org/10.1007/978-14615-0195-4_4

Singarimbun, M. (1997). Seksualitas dan Ketahanan Keluarga. Populasi, 8(1), 47-53. https://doi.org/10.22146/jp.11577

Sudira, P. (n.d.). Sumpah Pemuda dan Pendidikan Identitas Diri.

Sudrajat, D., \& Moha, M. I. (2019). Resume Ragam Penelitian Kualitatif. https://doi.org/10.31227/osf.io/wtncz

Sutopo, O. R., \& Meiji, N. H. P. (2017). Kapasitas Refleksif Pemuda dalam Transisi Menuju Dunia Kerja. JSW (Jurnal Sosiologi Walisongo), 1(1), 1 16. https://doi.org/10.21580/jsw.2017.1.1.1934

Syukur, Y. (2014). Open Booking Online (BO): Prostitusi di Facebook dalam Tinjauan Antropologi Simbolik. Jurnal Studi Pemuda, 3(2), 8998. https://doi.org/10.22146/studipemudaugm.32025

Tan, R.-A. (2020). "We Are Not Red and White, We Are Morning Star!" Internal Colonization, Indigenous Identity, and the Idea of Indonesia. Journal of International Affairs, 73(2), 271-284. https:// www.jstor.org/stable/26939984

Ulfiah, \& Hannah, N. (2018). Prostitusi Remaja dan Ketahanan Keluarga. Psikoislamedia: Jurnal Psikologi, 3(2), 163-187. https://doi.org/ 10.22373/psikoislamedia.v3i2.5630

UNICEF. (2020). Situasi Anak di Indonesia - Tren, Peluang, dan Tantangan dalam Memenuhi Hak-hak Anak. UNICEF. https://www.unicef.org/ indonesia/id/laporan/situasi-anak-di-indonesia-2020

Widodo, S. K. (2012). Memaknai Sumpah Pemuda di Era Reformasi. Humanika, 16(9). https://doi.org/10.14710/humanika.16.9.

Wijaya, H. (2019). Metode-Metode Penelitian dalam Penulisan Jurnal IImiah Elektronik. https://www.researchgate.net/publication/338235695

World Health Organization. (2014). Preventing suicide: A global imperative. World Health Organization. https://www.who.int/publications/i/ item/9789241564779 